Meta

Journal des traducteurs

Translators' Journal

\title{
Practical Hints on Greek and Latin
}

\section{James Jopes}

Volume 23, numéro 2, juin 1978

URI : https://id.erudit.org/iderudit/003270ar

DOI : https://doi.org/10.7202/003270ar

Aller au sommaire du numéro

Éditeur(s)

Les Presses de l'Université de Montréal

ISSN

0026-0452 (imprimé)

1492-1421 (numérique)

Découvrir la revue

Citer cet article

Jopes, J. (1978). Practical Hints on Greek and Latin. Meta, 23(2), 148-153.

https://doi.org/10.7202/003270ar d'utilisation que vous pouvez consulter en ligne.

https://apropos.erudit.org/fr/usagers/politique-dutilisation/ 


\section{Practical Hints on Greek and Latin*}

For centuries, general education in Europe and the Americas gave pride of place to the study of Greek and Latin, and the focal point of this study was translating. At the same time, probably most commissioned translations involved these languages as source languages, and often even as target languages. As late as 1968, Theodore Savory (The Art of Translation, p. 60) could state that " more than half of all that had been written on the subject of translation» concerned the classical languages, and the reason for this was «the importance of these languages in the education of those who subsequently follow a literary life ». In recent years, however, translation, like other linguistic and philological disciplines, has outgrown its classical tutelage, and the «classics 》 now have only limited relevance to the work of commercial, scientific, or even literary translators.

Why have I ventured to offer some suggestions on a subject with so much previous literature and so little practical importance? Because Greek and Latin are still relevant, but in a different way, and the bulk of the previous literature will not help modern translators with the problems which they are most likely to encounter.

\section{Greek and Latin quotations}

Modern clients seldom order a new translation of a classical work, but the historical importance of Greek and Latin still obstinately surfaces, often where it is least expected. Anyone who translates many scientific studies, for example, will eventually find some Greek or Latin quotations within papers in a modern source language. Greek and Latin are still common not only in proverbial openings and historical footnotes, but also in references to early modern authors, especially in historical reviews of topics in such areas as zoology, in which important work was published in Latin as late as the nineteenth century. Perhaps inevitably, these passages often must be translated by translators whose strength is in the modern source language, and who have only a limited knowledge of the

* From a workshop on \& The other languages in Canada 》 at the A.T.I.O. convention in Ottawa, October 15, 1976. My thanks are due to Dr. Vladimir Nekrassoff of A.T.I.O. for suggesting this paper, and to Dr. John Grear of the Herbarium of the University of Toronto for his helpful discussion of my remarks on botanical Latin. 
ancient source language, usually gleaned from a few university courses in the classical languages. In such circumstances, questions such as how to embody Thucydides' terse rhetoric in an original modern rendition of Pericles' Funeral Oration, or whether Vergil should be translated in prose or in verse are not relevant. The relevant problem is how to produce a uniform and consistent translation, of satisfactory quality, of a text involving portions in these less familiar languages; or how a person with some training only in classical Latin should approach the various non-classical types of Latin which are likely to occur in quotations. The difficulties which actually arise may seem elementary to readers with a classical background, but it is precisely these simple problems, too easily ignored by busy translators and the agencies which hire them, that it may still be useful to discuss.

\section{Use of published translations}

If we have a quotation from a major classical author, an obvious solution is to copy a published translation; but even this must not be done mechanically. There are always several published translations available, and they are emphatically not all alike. We all know how different translations of the same text may appear, but we must also remember that translations of the classics are based on different modern editions of the source text, which follow different manuscript readings and employ different emendations. Added to this is the fact that many translations still in use have long been dated. With such a wide range of variation, it is quite possible that mechanical copying of any translation available may give us a version which is nonsense in the context in which our modern author quotes the passage. For example, if a modern anthropological study quotes passages from Greek drama to illustrate the open attitude of the Greeks towards the sexual relations of their gods, an expurgated Victorian translation of these passages could be disastrous. We must find a translation which follows the same version of the source text quoted by our author, and translates it appropriately for his purpose in quoting it.

Once we have selected a published translation, we must use it consistently. If we copy «the length of Plato's visit », for example, from a translation, and the same Greek passage is quoted again a few pages later, we must not then write «the duration of Plato's stay ». Our reader may try to locate these words in the previous quotation.

\section{Transliteration}

Another elementary matter which may cause difficulties is Greek transliteration. Since classical civilization was so different socially and technologically from our own, many terms - such as administrative titles with no reasonable modern equivalent, or systematic philosophical concepts which would take on different meanings from later philosophies if expressed in a modern language - are best left untranslated. These terms, and proper names - and also any Greek appearing in publications not using Greek print - may have to be transliterated. In the past, it has been customary to transliterate Greek into English via Latin. 
However, many recent scholars have preferred to move directly from Greek to English. Thus the (sometimes civilian) officials known as «generals》 in ancient Greece may be rendered as strategoi (sing. strategos) as well as strategi (sing. strategus). Also $k$ may appear where we find $c$ in earlier sources, and $a i$ where we find $a e$. It is important that we know these are not different words, and that we be consistent in our own usage, in order not to confuse our reader.

In this connection, we must also be aware that different conventions regarding our common classical heritage have become established in different modern languages. $I$ have seen one case in which a German author referred to an ancient town as «Schedia». The translator, correctly following rules for transliterating from German to English, wrote «Shedia », for which his reader might have searched unsuccessfully in classical atlases. Verifications of the Greek - always the best procedure - gave a spelling which could be transliterated into English directly as «Skhedia», or via Latin as «Schedia». Usually Germans do not transliterate Greek via Latin, but perhaps this author had achieved the same effect by «germanizing 》 the word.

These differences between modern languages occur most often with respect to proper names. For example, the Roman historian whom we call Livy in English is known in French as Tite-Live ; the equivalence of these names becomes intelligible only from his full Latin name, Titus Livius Andronicus.

Incidentally, if our reader may want to reconstruct a Greek word from our transliteration, we should write $\bar{e}$ for eta to differentiate it from epsilon, and $\bar{o}$ for omega as opposed to omicron.

\section{Non-classical idioms}

I have mentioned that non-classical types of Latin may present difficulties. It is important to be aware of these different types of Latin, not only because today they may occur as frequently as classical Latin, but because it is precisely these passages that we have to translate ourselves, since published translations will not be available.

«Unclassical $»$ features characterize even some ancient sources. Inscriptions (epigraphy) and texts preserved not on parchment manuscripts, but on exhumed papyri (papyrology) may employ unusual grammar and orthography, usually surrounded by symbols serving to indicate the condition of the actual stone or papyrus - e.g., brackets around letters conjectured by the modern editor, a number of suspension points equal to the number of letters effaced at a certain point, etc. Naturally, these missing letters will not correspond in their number or position in a translation, so that it is meaningless to copy these symbols in our target language; translators who are intimidated by the symbols have been known to attempt this.

More frequently, of course, we will find unclassical features in quotations from early modern sources in mediaeval or later Latin, particularly in specialized areas such as medicine, law, or Church Latin. The simpler syntax of some 
mediaeval Latin - e.g., the use of quia with the indicative instead of the accusative and infinitive for indirect statements - may pose no problem; but the vocabulary may not be found, or may not be found with the correct meaning, in standard classical dictionaries. Various sources such as a dictionary of mediaeval Latin, or the more general (but so far incomplete) Oxford Latin Dictionary should be used whenever they are appropriate.

In such cases, moreover, it is most helpful to gain some acquaintance with the period and genre in question. We may illustrate this by taking a closer look at what is perhaps the best example of a special type of Latin still widely used : botanical Latin.

\section{Botanical Latin}

Its origin dates back to Aristotle's pupil Theophrastus, who elaborated Greek terminology to describe plants. Theophrastus' terminology, introduced into Latin by Roman authors, provided the rudiments of modern botanical terminology. But the rapid expansion of modern discoveries in plant anatomy later necessitated so many new terms that, to conserve scientific precision and economy in their plant descriptions, Linnaeus and his successors perfected a botanical Latin with its own rules and definitions. The final product is so unclassical that some botanists consider it an «autonomous » language ; William T. Stearn even complains that «professors of the classics are particularly liable to err through ignorance of botanical tradition $\gg$ (Botanical Latin, p. 156). He offers the following example :

species scapo conspicue bracteato pubescenti, petalis glandulosis, antheris gynoecio paulo longioribus.

The correct translation is :

species with a strikingly bracteate, pubescent scape, glandular petals, and anthers a little longer than the gynoecium.

But according to Stearn, a classical Latinist would probably read this as follows :

kind with the stem conspicuously glistening like gold and reaching the age of puberty with the thin metal plates full of kernels, with the medicines made from flowers a little longer than the women's apartment.

Now, this is somewhat exaggerated. As an experiment, I attempted to translate these words pretending that I knew nothing of botanical Latin, and using only a classical dictionary and common sense. The latter faculty alone would have told me that species here means «species », even if my dictionary had not; and I found that Vergil had already used pubes to describe the downy hairs covering a plant, and not some curious phase of vegetable concupiscence. Yet although I would have known that the "plates » described by petalis must by phytic and not metallic, I might have hesitated between «leaf» and «petal»; and I would have been quite puzzled by the spelling and meaning of gynoecium.

Johannes Roeper, a nineteenth-century botanist, coined this word to designate collectively the female sexual organs - i.e., the pistil or pistils - of a 
plant. He derived it from the stem of the Greek word for \& woman », gyn-, and the stem (oik-) of the word oikos, "house », plus the suffix -eion. Now, classical Greek had a word gynaikeion (Latin gynaeceum), which signified the women's apartment in a (sexually segregated) Greek home. In spite of its meaning, however, this classical word was not derived from oikos, but from a longer form of the stem of the word for «woman», gynaik-, plus the same suffix. This curious resemblance of form and meaning confused even botanists, many of whom mistakenly conformed to the «classical spelling » until the matter was unraveled by A.H. Church (J. Bot., London, $57: 220-223$ ).

Obviously the vocabulary of botanical Latin is, in a sense, " autonomous », and the translator must acquaint himself with the botanical tradition. On the other hand, the syntax and inflection remain Latin, and another factor which the translator must bear in mind is that some contemporary botanists in North America may be liable to err through ignorance of Latin inflections. This may be exemplified by the following gem from the Memoirs of the New York Botanical Gardens (Vol. 26, no. 1, p. 37) :

Frutex, frutex scandems, vel arbor parva... Foliola $11-33$ (5 - $16-$ juga), pubescentia vel glabra, plerumque minus quam $3 \mathrm{~cm}$ longa, rarior $5 \mathrm{~cm}$ longa; apice plerumque rotundatus; calyce, bracteae et inflorescentia cum pili glanduliferi munita vel eglandulosa.

Fortunately the author also provides an English description, which makes clear his intended meaning :

Shrubs, scandent shrubs or small trees... Leaflets $11-13(5-16-$ jugate), pubescent or glabrous, usually less than $3 \mathrm{~cm}$ long, rarely up to $5 \mathrm{~cm}$ long; the apex usually rounded; glandular hairs present on calyx, bracts and inflorescence, or absent.

The reader may spot the obvious errors; what interests us is how these errors would be likely to mislead a Latinist with respect to the meaning. For example, the masculine rotundatus makes it quite reasonable to suppose that the author is no longer describing the leaves, but returning to the masculine frutex; one might also feel obliged to construe the final portion of the description in some peculiar manner in order to accommodate the ablative calyce. A botanist might be less likely to be misled by these mistakes. Because he knows the order in which the different parts of a plant will be described and what properties of each part are likely to be mentioned - and perhaps precisely because he is accustomed to ignore such elements as gender and case - he should divine that it is the leaf apex that is rounded. The moral for translators, however, is that we must know not only the legitimate variations, but also what kind of mistakes may be expected from a given type of source.

There is a common feature in all the points which $I$ have discussed : The proper handling of mediaeval Latin, botanical Latin, Greek transliteration, discussions of classical topics written in different modern languages, and even the intelligent plagiarizing of published translations of classical authors require a knowledge of the specific traditions in question. The classical languages represent a long and varied development, and their occasional occurrence in modern 
works should not be brushed aside as an unimportant auxiliary task. Although the absolute number of words accounted for by the ancient language itself may be relatively small, carelessness can mar the quality of an entire translation in a way which will be noticed by attentive readers. If a specialist in the ancient language cannot be called upon to collaborate, a little thoughtful research, at least, would be helpful.

JAMES JOPE 